Article

\title{
Effect of Annealing Temperature and Oxygen Flow in the Properties of Ion Beam Sputtered $\mathrm{SnO}_{2-x}$ Thin Films
}

\author{
Chun-Min Wang ${ }^{1}$, Chun-Chieh Huang ${ }^{2, *}$, Jui-Chao Kuo ${ }^{1, \dagger}$, Dipti Ranjan Sahu ${ }^{3, \dagger}$ and \\ Jow-Lay Huang $1,4,5,6, \dagger$
}

${ }^{1}$ Department of Materials Science and Engineering, National Cheng Kung University, No. 1, University Road, Tainan 701, Taiwan; E-Mails: n5896114@mail.ncku.edu.tw (C.-M.W.); jckuo@mail.ncku.edu.tw (J.-C.K.); jlh888@mail.ncku.edu.tw (J.-L.H.)

2 Department of Electrical Engineering, Cheng Shiu University, No. 840, Chengcing Road, Niaosong Township, Kaohsiung 833, Taiwan

${ }^{3}$ Amity Institute of Nanotechnology, Amity University, Sector 125, Noida, India;

E-Mail: dsahu@amity.edu

${ }^{4}$ Department of Chemical and Materials Engineering, National University of Kaohsiung,

No. 700, Kaohsiung University Road, Nan-Tzu District, Kaohsiung 811, Taiwan

${ }^{5}$ Center for Micro/Nano Science and Technology, National Cheng Kung University, Tainan 701, Taiwan

${ }^{6}$ Research Center for Energy Technology and Strategy, National Cheng Kung University, Tainan 701, Taiwan

$\dagger$ These authors contributed equally to this work.

* Author to whom correspondence should be addressed; E-Mail: jymtwn@ gmail.com; Tel.: +886-7-7310606 (ext. 3427); Fax: +886-7-7337390.

Academic Editor: Teen-Hang Meen

Received: 30 June 2015 / Accepted: 6 August 2015 / Published: 14 August 2015

\begin{abstract}
Tin oxide $\left(\mathrm{SnO}_{2-\mathrm{x}}\right)$ thin films were prepared under various flow ratios of $\mathrm{O}_{2} /\left(\mathrm{O}_{2}+\mathrm{Ar}\right)$ on unheated glass substrate using the ion beam sputtering (IBS) deposition technique. This work studied the effects of the flow ratio of $\mathrm{O}_{2} /\left(\mathrm{O}_{2}+\mathrm{Ar}\right)$, chamber pressures and post-annealing treatment on the physical properties of $\mathrm{SnO}_{2}$ thin films. It was found that annealing affects the crystal quality of the films as seen from both X-ray diffraction (XRD) and transmission electron microscopy (TEM) analysis. In addition, the surface RMS roughness was measured with atomic force microscopy (AFM). Auger electron spectroscopy (AES) analysis was used to obtain the changes of elemental distribution between tin and
\end{abstract}


oxygen atomic concentration. The electrical property is discussed with attention to the structure factor.

Keywords: $\mathrm{SnO}_{2}$; transparent conductive oxide (TCO); oxygen flow ratio; annealing

\section{Introduction}

The most widely-used materials for transparent conductive oxide (TCO) thin films are zinc oxide $(\mathrm{ZnO})$, tin oxide $\left(\mathrm{SnO}_{2}\right)$ and indium oxide $\left(\mathrm{In}_{2} \mathrm{O}_{3}\right) \cdot \mathrm{SnO}_{2}$ thin films have been developed and applied in different fields, such as solar cells, gas sensors and light-emitting diodes (LEDs) [1-5] because they have the advantages of their low electrical resistance and high optical transparency in the visible range of the electromagnetic spectrum. Furthermore, they are inexpensive and also stable against thermal and chemical attacks at high temperature.

A number of studies have been reported on the effect of the oxygen gas ratio [6], substrate temperature and type, annealing temperature [7-9] and doping elements [10-12] on improving the structural, electrical and optical properties of the $\mathrm{SnO}_{2}$ thin film in the past few decades. The thin films of pure or doped $\mathrm{SnO}_{2}$ can be prepared by different deposition techniques, including sol-gel-dip coatings [13], metal-organic chemical vapor deposition (MOCVD) [14,15], chemical bath deposition (CBD) [16], spray pyrolysis [17], electron beam evaporation [18] and sputtering [19-22]. However, it is necessary to carry out either a heat treatment of substrates during the deposition process or the post-annealing procedure to obtain low resistivity and to retain high transmittance. Here, the ion beam sputtering (IBS) technique was applied to achieve high quality films, because of its high energy of incoming ions and the low deposition rate.

In general, $\mathrm{SnO}_{2}$ thin films have defects, such as oxygen vacancies [23], which act as donors in the $\mathrm{SnO}_{2}$ matrix and increase the electron density in the conduction band. This is called the n-type conduction. The formation of excess oxygen vacancies results in decreasing film quality. Thus, increasing the conductivity of $\mathrm{SnO}_{2-\mathrm{x}}$ lies in a narrow range of oxygen pressure [24]. The post-heat treatment reduces residual stress and the lattice mismatch to obtain good electrical conductivity [25].

In the present work, we investigated the effects of the flow ratio of $\mathrm{O}_{2} /\left(\mathrm{O}_{2}+\mathrm{Ar}\right)$, chamber pressures and post-annealing treatment on the physical properties of $\mathrm{SnO}_{2}$ thin films.

\section{Results and Discussion}

\subsection{Structural and Morphological Properties}

Figure 1 shows typical XRD patterns of the as-deposited and annealed $\mathrm{SnO}_{2-\mathrm{x}}$ films where they were prepared at a flow ratio of 0.5 of $\mathrm{O}_{2} /\left(\mathrm{O}_{2}+\mathrm{Ar}\right)$ at $4.7 \times 10^{-2} \mathrm{~Pa}$. The structures of the as-deposited and the annealed $\mathrm{SnO}_{2-x}$ films deposited at $4 \times 10^{-2} \mathrm{~Pa}$ were almost the same as that prepared. It is observed that the films as-deposited and annealed at $350{ }^{\circ} \mathrm{C}$ were the typical amorphous structure, as indicated in Figure 1a,b. However, $\mathrm{SnO}_{2-\mathrm{x}}$ films annealed at $360{ }^{\circ} \mathrm{C}$ have crystallization without preferred orientations, as shown in Figure 1c. A similar result was reported by Wulff et al. [26] for ITO thin 
films. Further, the $\{101\}$ peak of $\mathrm{SnO}$ phase appeared at $400{ }^{\circ} \mathrm{C}$, as shown in Figure 1f, which was also reported by Choe et al. [9].

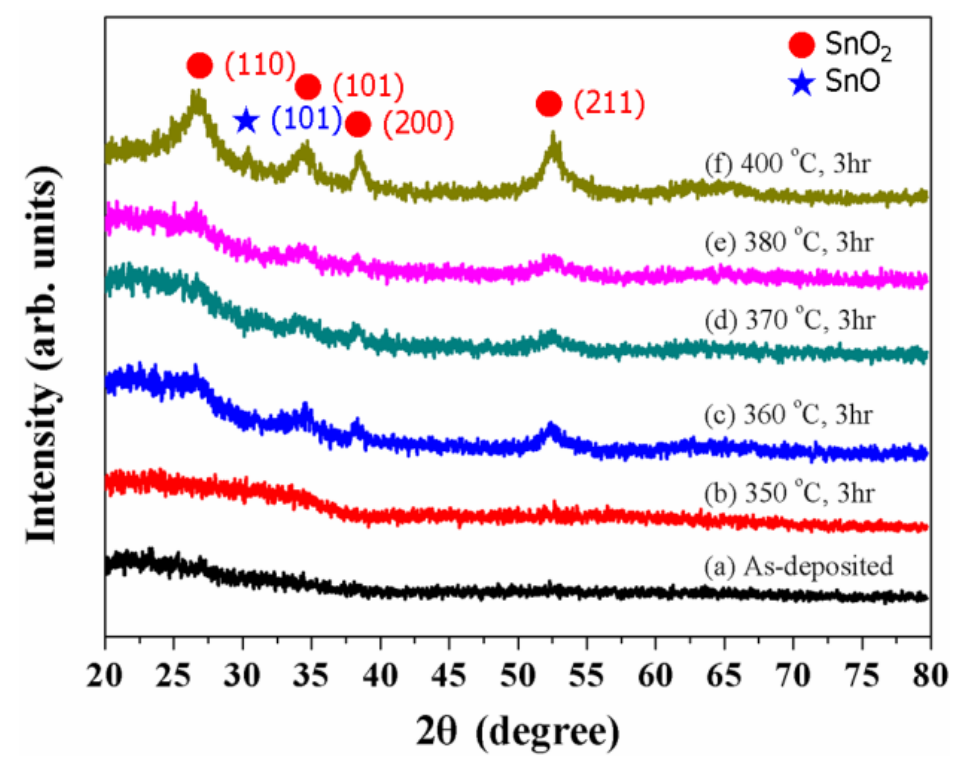

Figure 1. $\mathrm{XRD}$ patterns of $\mathrm{SnO}_{2-\mathrm{x}}$ thin films (a) as-deposited and annealed for $3 \mathrm{~h}$ at (b) $350{ }^{\circ} \mathrm{C}$; (c) $360{ }^{\circ} \mathrm{C}$; (d) $370{ }^{\circ} \mathrm{C}$; (e) $380{ }^{\circ} \mathrm{C}$ and (f) $400{ }^{\circ} \mathrm{C}$ at $4.7 \times 10^{-2} \mathrm{~Pa}$.

Figure 2 shows the surface morphology of $\mathrm{SnO}_{2-x}$ films prepared with low and high flow ratios of 0.33 and 0.71 at $4 \times 10^{-2} \mathrm{~Pa}$. It is observed that the as-deposited films have similar and uniform surface morphologies. However, cracks are found at a high $\mathrm{O}_{2} /\left(\mathrm{O}_{2}+\mathrm{Ar}\right)$ flow ratio of 0.71 after $380{ }^{\circ} \mathrm{C}$ annealing.
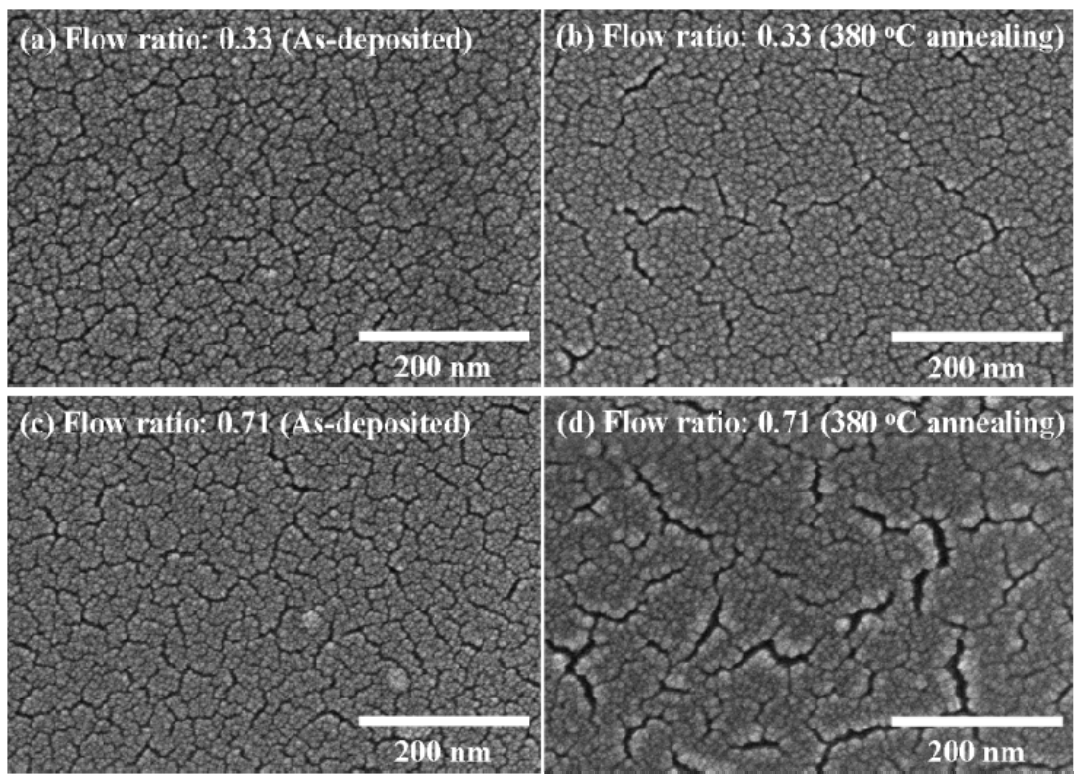

Figure 2. FE-SEM micrographs of the $\mathrm{SnO}_{2-\mathrm{x}}$ thin films prepared at various flow ratios and a working pressure of $4 \times 10^{-2} \mathrm{~Pa}$. The flow ratio of 0.33 of $\mathrm{O}_{2} /\left(\mathrm{O}_{2}+\mathrm{Ar}\right.$ ) (a) for as-deposited films; (b) $380{ }^{\circ} \mathrm{C}$ annealing and the flow ratio of 0.71 of $\mathrm{O}_{2} /\left(\mathrm{O}_{2}+\mathrm{Ar}\right.$ ) (c) for as-deposited films; (d) $380^{\circ} \mathrm{C}$ annealing. 
In addition to SEM analysis, TEM was employed to characterize the cross-section of $\mathrm{SnO}_{2-\mathrm{x}}$ films. The as-deposited films with a high flow ratio of 0.71 of $\mathrm{O}_{2} /\left(\mathrm{O}_{2}+\mathrm{Ar}\right)$ at $4 \times 10^{-2}$ and $4.7 \times 10^{-2} \mathrm{~Pa}$ reveal very high adherence and a smooth and uniform surface, as shown in Figure 3a,c. After annealing at $370{ }^{\circ} \mathrm{C}$ for $3 \mathrm{~h}$, the films show looser, thinner interfaces than as-deposited films, because they were cracked and have enhanced large spaces between grains after high temperature Ar annealing, as shown in Figure 3b,d.

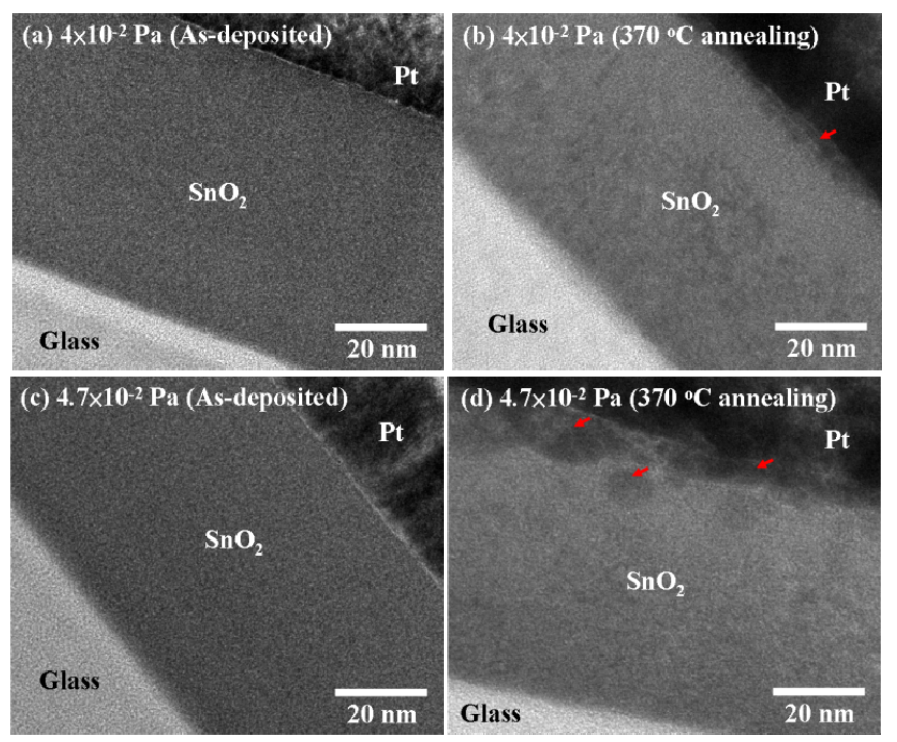

Figure 3. The cross-section images of bright field high-resolution TEM analysis at the same flow ratio of 0.71 of $\mathrm{O}_{2} /\left(\mathrm{O}_{2}+\mathrm{Ar}\right)$ and a working pressure of $4 \times 10^{-2} \mathrm{~Pa}$ (a) for as-deposited films; (b) $370{ }^{\circ} \mathrm{C}$ annealing and a working pressure of $4.7 \times 10^{-2} \mathrm{~Pa}$ (c) for as-deposited films; (d) $370{ }^{\circ} \mathrm{C}$ annealing.
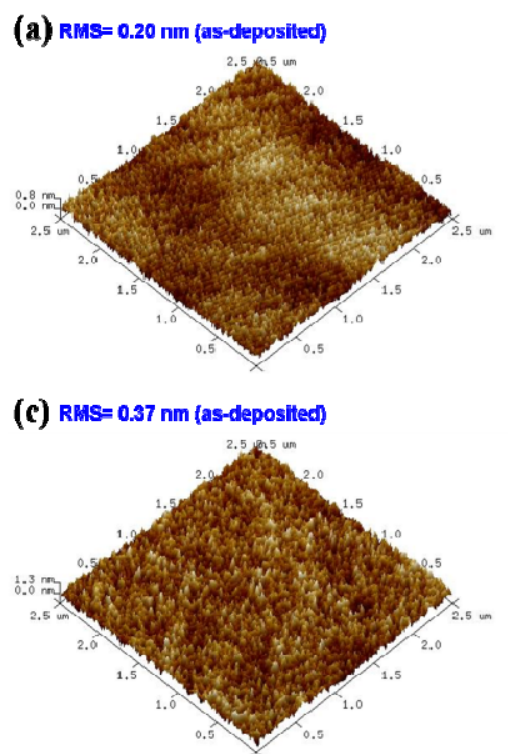

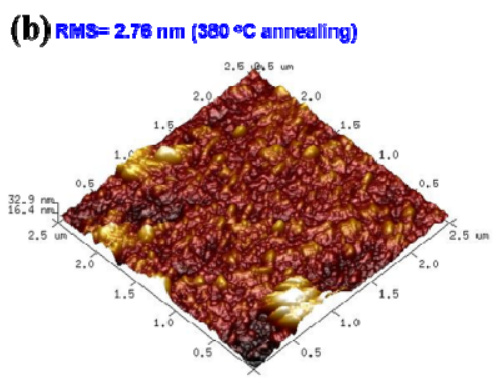

(d) RMS $=0.585 \mathrm{~nm}\left(380^{\circ} \mathrm{C}\right.$ annealing)

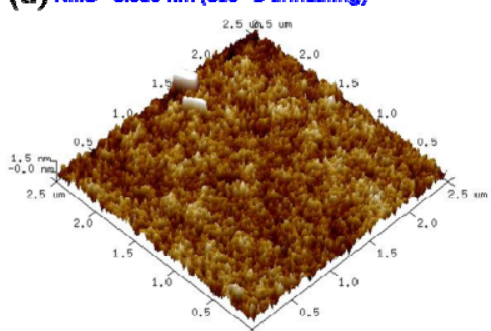

Figure 4. 3D AFM images with a scan area of $2.5 \mu \mathrm{m} \times 2.5 \mu \mathrm{m}$ : (a) as-deposited; (b) $380{ }^{\circ} \mathrm{C}$ annealing $\mathrm{SnO}_{2-\mathrm{x}}$ thin films at the flow ratio of 0.5 of $\mathrm{O}_{2} /\left(\mathrm{O}_{2}+\mathrm{Ar}\right)$ and a working pressure of $4 \times 10^{-2} \mathrm{~Pa}$. (c) As-deposited; (d) $380{ }^{\circ} \mathrm{C}$ annealing $\mathrm{SnO}_{2-\mathrm{x}}$ thin films at the flow ratio of 0.5 of $\mathrm{O}_{2} /\left(\mathrm{O}_{2}+\mathrm{Ar}\right)$ and a working pressure of $4.7 \times 10^{-2} \mathrm{~Pa}$. 
The AFM images that illustrate the surface topology and the root mean square (RMS) surface roughness of $\mathrm{SnO}_{2-\mathrm{x}}$ films before and after $380{ }^{\circ} \mathrm{C}$ annealing are shown in Figure 4 . It is clear that the surface morphology of the as-deposited film and $380{ }^{\circ} \mathrm{C}$ annealing at the flow ratio of 0.5 of $\mathrm{O}_{2} /\left(\mathrm{O}_{2}+\mathrm{Ar}\right)$ do not significantly change at a working pressure of $4.7 \times 10^{-2} \mathrm{~Pa}$, as shown in Figure $4 \mathrm{c}$,d. However, the surface morphology of the film changes dramatically from Figure $4 \mathrm{a}$ to Figure $4 \mathrm{~b}$. The surface roughness of the as-deposited film at $4 \times 10^{-2} \mathrm{~Pa}$ is $0.20 \mathrm{~nm}$. The film annealed at $380{ }^{\circ} \mathrm{C}$ shows an increase of surface roughness from $0.20 \mathrm{~nm}$ to $2.76 \mathrm{~nm}$. The increase in film roughness at a working pressure of $4 \times 10^{-2} \mathrm{~Pa}$ can be explained with surface melt after $380^{\circ} \mathrm{C}$ annealing. However, it does not have an obvious structure transformation at a working pressure of $4.7 \times 10^{-2} \mathrm{~Pa}$.

\subsection{Electrical Properties}

Figure 5 shows the variation of electrical resistivity of $\mathrm{SnO}_{2}$ thin films with various flow ratios of $\mathrm{O}_{2} /\left(\mathrm{O}_{2}+\right.$ Ar $)$ at the annealing temperature from $350{ }^{\circ} \mathrm{C}$ to $380{ }^{\circ} \mathrm{C}$ and a working pressure of $4.7 \times 10^{-2} \mathrm{~Pa}$.

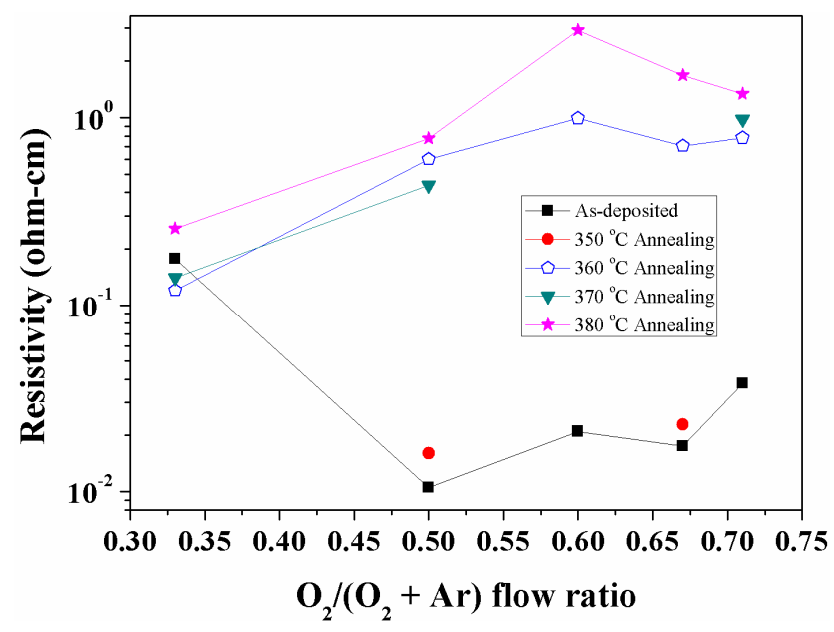

Figure 5. The variation of the electrical resistivity of $\mathrm{SnO}_{2-\mathrm{x}}$ thin films with various flow ratios of $\mathrm{O}_{2} /\left(\mathrm{O}_{2}+\mathrm{Ar}\right)$ at the annealing temperature from $350{ }^{\circ} \mathrm{C}$ to $380{ }^{\circ} \mathrm{C}$ and a working pressure of $4.7 \times 10^{-2} \mathrm{~Pa}$.

The as-deposited films show the lowest resistivity of $1.05 \times 10^{-2} \Omega \mathrm{cm}$ at the flow ratio of 0.5 . A strong dependence of resistivity on the oxygen flow ratio was observed. It is observed that the resistivity increased about two orders of higher magnitude at $360{ }^{\circ} \mathrm{C}$ than that of the as-deposited films, except at the flow ratio of 0.33 . This is due to the change in the structure from amorphous to crystallization and mainly the decrease of carrier concentration with a serious crack formation at a higher flow ratio, as depicted by SEM and TEM analyses. Shanthi et al. [27] reported that the chemisorbed oxygen removes oxygen vacancies at high temperature annealing and increases chemisorbed oxygen at the surfaces and grain boundaries, which results from further lowering of free electrons. The degree of reduction in carrier concentration was high for $\mathrm{SnO}_{2}$ deposited at a high flow ratio. At the oxygen flow ratio of 0.3 , the initial decrease in resistivity at the annealing temperature from $360{ }^{\circ} \mathrm{C}$ to $370{ }^{\circ} \mathrm{C}$ is due to the number of oxygen vacancies and excess metal ions arising from the non-stoichiometry, which was also reported by $\mathrm{Ku}$ et al. [28]. The flow ratio of 0.6 has the highest resistivity due to its lowest mobility 
or carrier concentration at high and low working pressure after annealing. Williams and Ho [29,30] reported the conductivity performance of $\mathrm{SnO}_{2}$ sensors, which were very a sensitive probe of changes in surface chemistry due to electrons transfer, such as the parameters of oxygen partial pressure and crystallite size, etc.

Figure 6 shows the AES depth profile of as-deposited and $380{ }^{\circ} \mathrm{C}$ annealing $\mathrm{SnO}_{2-\mathrm{x}}$ thin films at the flow ratio of 0.5 of $\mathrm{O}_{2} /\left(\mathrm{O}_{2}+\mathrm{Ar}\right)$ and a working pressure of $4.7 \times 10^{-2} \mathrm{~Pa}$. The depth profile shows the change of atomic percent at the sputtering time from 0 to $120 \mathrm{~s}$. The change of composition after the annealing temperature of $380{ }^{\circ} \mathrm{C}$ indicates the decrease of oxygen atoms and the increase of tin atoms in the thin film surface. The AES profiles are usually used for chemical composition analysis. We used this technique to confirm the correction for the thickness and atomic percentage with TEM.

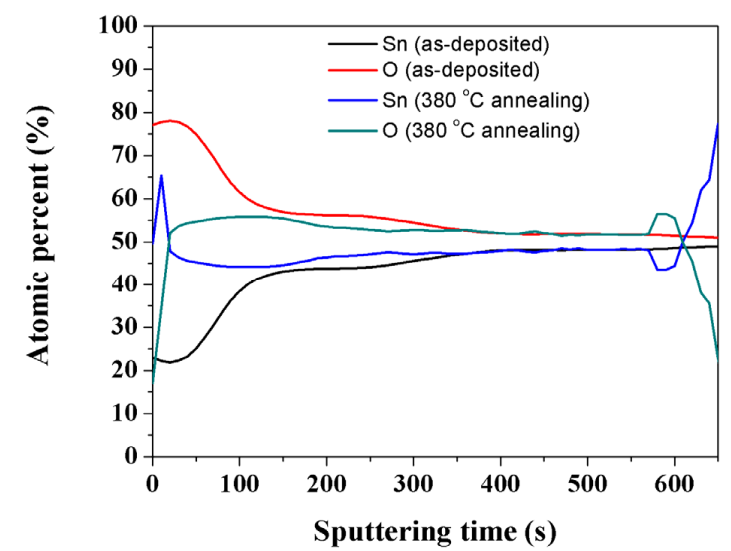

Figure 6. Atomic depth profile of the as-deposited and $380{ }^{\circ} \mathrm{C}$ annealing $\mathrm{SnO}_{2-\mathrm{x}}$ thin films at the flow ratio of 0.5 of $\mathrm{O}_{2} /\left(\mathrm{O}_{2}+\mathrm{Ar}\right)$ and a working pressure of $4.7 \times 10^{-2} \mathrm{~Pa}$.

\section{Experimental Section}

Thin films of $\mathrm{SnO}_{2}$ were sputtered from a diameter of 4-inch using a high purity of 99.99 wt\% $\mathrm{SnO}_{2}$ ceramic target (Ultimate Materials Technology Co., Hsinchu, Taiwan) in an atmosphere of argon and oxygen gases having $99.999 \%$ purity. $\mathrm{SnO}_{2}$ layers of about $60 \mathrm{~nm}$ in thickness were deposited onto the glass substrates (Corning EAGLE 2000 AMLCD glass, Taichung, Taiwan) using an ion beam sputtering deposition system, the Commonwealth Scientific IBS250 Kaufman ion source, at the conditions of $600 \mathrm{~V}$ and $20 \mathrm{~A}$, where the glass substrates were heated at $373 \mathrm{~K}$. The vacuum of the ion beam sputtering chamber was maintained at $3 \times 10^{-4} \mathrm{~Pa}$ before deposition. In the case of ion beam sputtering of $\mathrm{SnO}_{2}$ films, the flow ratio of mixture gas composition $\mathrm{O}_{2} /\left(\mathrm{O}_{2}+\mathrm{Ar}\right)$ was controlled from 0.33 to 0.71 at a working pressure of $4.7 \times 10^{-2}$ and $4.0 \times 10^{-2} \mathrm{~Pa}$ during deposition. The as-deposited $\mathrm{SnO}_{2}$ films were subsequently annealed in $\mathrm{Ar}$ atmosphere from $350{ }^{\circ} \mathrm{C}$ to $400{ }^{\circ} \mathrm{C}$ for $3 \mathrm{~h}$. The phase and lattice structure of the films were analyzed using grazing angle X-ray diffraction (XRD) (D/Max2500 Rigaku, Tokyo, Japan) with $\mathrm{Cu} \mathrm{K} \alpha$ radiation $(\lambda=1.5406 \AA$ ) at $40 \mathrm{kV}$ and $100 \mathrm{~mA}$. The field-emission scanning electron microscope (FE-SEM) (S4800-I Hitachi, Tokyo, Japan) was used to observe the surface topography of the films before and after annealing at $15 \mathrm{kV}$. The cross-section morphologies of as-deposited and post-annealing films were investigated by an ultrahigh resolution transmission electron microscopy (HR-TEM) (JEM-2100F, JEOL, Peabody, MA, USA) at $200 \mathrm{kV}$, which was equipped with an energy dispersive spectrometer (EDS) INCA x-stream-2 Oxford, U.K., 
for chemical elemental analysis. For EDS measurements, a silicon drift detector of $80 \mathrm{~mm}^{2}$ was used. TEM samples were prepared using focus ion beams SMI3050SE (SEIKO, Chiba, Japan) with the first milling at $30 \mathrm{kV}$ and $100 \mathrm{pA}$ and the final milling at $5 \mathrm{kV}$ and $40 \mathrm{pA}$. After that, Pt was coated on the $\mathrm{SnO}_{2}$ surface to protect thin films from damage. The Hall effect measurement setup AHM-800A with Advance Design Technology in van der Pauw configuration was used to study the electrical properties. Atomic force microscopy (AFM) (Force Precision Instrument Co., Taipei, Taiwan) was used to evaluate the surface roughness of the films by tapping mode. The sample surface was probed with a silicon tip of $10 \mathrm{~nm}$ in radius oscillating at its resonant frequency between 200 and $400 \mathrm{kHz}$. The scan area was $2.5 \mu \mathrm{m} \times 2.5 \mu \mathrm{m}$, and the scan rate was $0.3 \mathrm{~Hz}$. The compositions and depth profile of the films were determined by the Auger Electron Spectroscopy (AES) (Microlab 350, Thermo Fisher Scientific, Warrangton, UK).

\section{Conclusions}

As-deposited $\mathrm{SnO}_{2}$ thin films show an amorphous structure, and crystallization occurs at $360{ }^{\circ} \mathrm{C}$. The resistivity of the film depends strongly on the oxygen flow ratio of 0.5 and above, due to the decrease in carrier concentration. In the case of an oxygen flow ratio of 0.3 , metallic ions are dominated, and stable conductivity after annealing is observed due to the change in the numbers of oxygen vacancies and excess metal ions. Therefore, the dependence of resistivity on the oxygen partial pressure could be interesting in view of the use of these materials as oxygen sensors.

\section{Acknowledgments}

The authors acknowledge Sean Wu for the assistance in the measurement apparatus of the Hall effect at the College of Applied Design, TungFang Design Institute. The authors wish to thank H.C. Liu of the Department of Materials Science and Engineering, National Cheng Kung University, for giving great help with the AFM instrument in this work. This project was financially supported by the National Science Council of Taiwan with Grant No. 101-2221-E-006-124-MY3.

\section{Author Contributions}

All authors made contributions to this manuscript. Chun-Min Wang performed the experimental works, analyzed the results and wrote the manuscript. Chun-Chieh Huang and Dipti Ranjan Sahu greatly contributed to the concept and the design of the experimental parameters. Jui-Chao Kuo strongly contributed to the discussion of all of the results and revised the manuscript. Jow-Lay Huang provided overall guidance.

\section{Conflicts of Interest}

The authors declare no conflict of interest.

\section{References}

1. Snaith, H.J.; Ducati, C. $\mathrm{SnO}_{2}$-based dye-sensitized hybrid solar cells exhibiting near unity absorbed photon-to-electron conversion efficiency. Nano Lett. 2010, 10, 1259-1265. [CrossRef] [PubMed] 
2. Nang Dinh, N.; Bernard, M.-C.; Hugot-Le Goff, A.; Stergiopoulos, T.; Falaras, P. Photoelectrochemical solar cells based on $\mathrm{SnO}_{2}$ nanocrystalline films. Comptes Rendus Chim. 2006, 9, 676-683. [CrossRef]

3. Tricoli, A.; Graf, M.; Pratsinis, S.E. Optimal doping for enhanced $\mathrm{SnO}_{2}$ sensitivity and thermal stability. Adv. Funct. Mater. 2008, 18, 1969-1976. [CrossRef]

4. Song, J.-O.; Seong, T.-Y. Highly transparent $\mathrm{Ag} / \mathrm{SnO}_{2}$ ohmic contact to p-type $\mathrm{GaN}$ for ultraviolet light-emitting diodes. Appl. Phys. Lett. 2004, 85, 6374-6376. [CrossRef]

5. Jeng, C.-C.; Chong, P.J.H.; Chiu, C.-C.; Jiang, G.-J.; Lin, H.-J.; Wu, R.-J.; Wu, C.-H. A dynamic equilibrium method for the $\mathrm{SnO}_{2}$-based ozone sensors using UV-LED continuous irradiation. Sens. Actuators B Chem. 2014, 195, 702-706. [CrossRef]

6. Lee, J. Effects of oxygen concentration on the properties of sputtered $\mathrm{SnO}_{2}: \mathrm{Sb}$ films deposited at low temperature. Thin Solid Films 2008, 516, 1386-1390. [CrossRef]

7. Khan, A.F.; Mehmood, M.; Rana, A.M.; Bhatti, M.T. Effect of annealing on electrical resistivity of RF-magnetron sputtered nanostructured $\mathrm{SnO}_{2}$ thin films. Appl. Surf. Sci. 2009, 255, 8562-8565. [CrossRef]

8. Rembeza, E.S.; Richard, O.; Landuyt, J.V. Influence of laser and isothermal treatments on microstructural properties of $\mathrm{SnO}_{2}$ films. Mater. Res. Bull. 1999, 34, 1527-1533. [CrossRef]

9. Choe, Y.-S.; Chung, J.-H.; Kim, D.-S.; Kim, G.-H.; Baik, H.K. Phase transformation and morphological evolution of ion-beam sputtered tin oxide films on silicon substrate. Mater. Res. Bull. 1999, 34, 1473-1479. [CrossRef]

10. Zhu, Q.; Ma, Q.; Buchholz, D.B.; Chang, R.P.H.; Bedzyk, M.J.; Mason, T.O. Structural and physical properties of transparent conducting, amorphous $\mathrm{Zn}$-doped $\mathrm{SnO}_{2}$ films. J. Appl. Phys. 2014, 115, 033512. [CrossRef]

11. Mohanapriya, P.; Pradeepkumar, R.; Victor Jaya, N.; Natarajan, T.S. Magnetic and optical properties of electrospun hollow nanofibers of $\mathrm{SnO}_{2}$ doped with Ce-ion. Appl. Phys. Lett. 2014, 105, 022406. [CrossRef]

12. Stjerna, B.; Olsson, E.; Granqvist, C.G. Optical and electrical properties of radio frequency sputtered tin oxide films doped with oxygen vacancies, F, Sb, or Mo. J. Appl. Phys. 1994, 76, 3797-3817. [CrossRef]

13. Floriano, E.A.; Scalvi, L.V.D.A.; Sambrano, J.R.; Geraldo, V. Evaluation of bulk and surfaces absorption edge energy of sol-gel-dip-coating $\mathrm{SnO}_{2}$ thin films. Mater. Res. 2010, 13, 437-443. [CrossRef]

14. Duverneuil, P.; Maury, F.; Pebere, N.; Senocq, F.; Vergnes, H. Chemical vapor deposition of $\mathrm{SnO}_{2}$ coatings on Ti plates for the preparation of electrocatalytic anodes. Surf. Coat. Technol. 2002, 151-152, 9-13. [CrossRef]

15. Feng, X.; Ma, J.; Yang, F.; Ji, F.; Zong, F.; Luan, C.; Ma, H. Transparent conducting $\mathrm{SnO}_{2}: \mathrm{Sb}$ epitaxial films prepared on $\alpha-\mathrm{Al}_{2} \mathrm{O}_{3}$ (0001) by MOCVD. Mater. Lett. 2008, 62, 1779-1781. [CrossRef]

16. Ebrahimiasl, S.; Yunus, W.M.Z.W.; Kassim, A.; Zainal, Z. Synthesis of nanocrystalline $\mathrm{SnO}_{\mathrm{x}}$ $(\mathrm{x}=1-2)$ thin film using a chemical bath deposition method with improved deposition time, temperature and pH. Sensors 2011, 11, 9207-9216. [CrossRef] [PubMed] 
17. Agashe, C.; Mahamuni, S. Competitive effects of film thickness and growth rate in spray pyrolytically deposited fluorine-doped tin dioxide films. Thin Solid Films 2010, 518, 4868-4873. [CrossRef]

18. Punitha, K.; Sivakumar, R.; Sanjeeviraja, C. Structural and surface morphological studies of magnesium tin oxide thin films. Energy Procedia 2012, 15, 312-317. [CrossRef]

19. Jäger, S.; Szyszka, B.; Szczyrbowski, J.; Bräuer, G. Comparison of transparent conductive oxide thin films prepared by a.c. and d.c. reactive magnetron sputtering. Surf. Coat. Technol. 1998, 98, 1304-1314. [CrossRef]

20. Ding, X.; Fang, F.; Jiang, J. Electrical and optical properties of N-doped $\mathrm{SnO}_{2}$ thin films prepared by magnetron sputtering. Surf. Coat. Technol. 2013, 231, 67-70. [CrossRef]

21. Becker, M.; Hamann, R.; Polity, A.; Meyer, B.K. Stannic oxide thin film growth via ion-beam-sputtering. Thin Solid Films 2014, 553, 26-29. [CrossRef]

22. Tosun, B.S.; Feist, R.K.; Gunawan, A.; Mkhoyan, K.A.; Campbell, S.A.; Aydil, E.S. Sputter deposition of semicrystalline tin dioxide films. Thin Solid Films 2012, 520, 2554-2561. [CrossRef]

23. Jarzebski, Z.M.; Marton, J.P. Physical properties of $\mathrm{SnO}_{2}$ materials: II. Electrical properties. J. Electrochem. Soc. 1976, 123, 299C-310C. [CrossRef]

24. Wang, C.-M.; Huang, C.-C.; Kuo, J.-C.; Lin, H.-T.; Huang, J.-L. Preparing transparent conductive $\mathrm{Sn} / \mathrm{SbO}_{2-\mathrm{x}}$ thin films by annealing bi-layer $\mathrm{Sb} / \mathrm{SnO}_{2}$ with pulse UV laser. Mater. Lett. 2012, 72, 29-31. [CrossRef]

25. Ordaz-Flores, A.; Bartolo-Pérez, P.; Castro-Rodríguez, R.; Oliva, A. Annealing effects on the mass diffusion of the CdS/ITO interface deposited by chemical bath deposition. Rev. Mex. Fís. 2006, $52,15-18$.

26. Wulff, H.; Quaas, M.; Steffen, H.; Hippler, R. In situ studies of diffusion and crystal growth in plasma deposited thin ITO films. Thin Solid Films 2000, 377-378, 418-424. [CrossRef]

27. Shanthi, E.; Banerjee, A.; Dutta, V.; Chopra, K.L. Annealing characteristics of tin oxide films prepared by spray pyrolysis. Thin Solid Films 1980, 71, 237-244. [CrossRef]

28. Ku, D.Y.; Kim, I.H.; Lee, I.; Lee, K.S.; Lee, T.S.; Jeong, J.H.; Cheong, B.; Baik, Y.J.; Kim, W.M. Structural and electrical properties of sputtered indium-zinc oxide thin films. Thin Solid Films 2006, 515, 1364-1369. [CrossRef]

29. Williams, D.E. Oxide Gas Sensors. In Encyclopedia of Materials: Science and Technology, 2nd ed.; Elsevier: Oxford, UK, 2001; pp. 6609-6613.

30. Ho, G.W. Gas Sensor with Nanostructured Oxide Semiconductor Materials. Sci. Adv. Mater. 2011, 3, 150-168. [CrossRef]

(C) 2015 by the authors; licensee MDPI, Basel, Switzerland. This article is an open access article distributed under the terms and conditions of the Creative Commons Attribution license (http://creativecommons.org/licenses/by/4.0/). 